\title{
ON THE NATURE OF THE PSYCHE
}<smiles>[O-]C([O-])O</smiles>

$$
\text { from }
$$

The Collected Works of C. G. Jung

VOLUME 8

B O L L I N E N S ER I E X X 


\section{PRINCETON / BOLLINGEN PAPERBACK EDITIONS FROM THE COLLECTED WORKS OF C. G. JUNG}

Aion (CW 9,ii)

Alchemical Studies (CW 13)

Analytical Psychology

Answer to Job

Archetypes and the Collective Unconscious (CW 9,i)

Aspects of the Feminine

Aspects of the Masculine

Basic Writings of C. G. Jung

The Development of Personality (CW 17)

Dreams

Essay on Contemporary Events

Essays on a Science of Mythology

The Essential Jung

Flying Saucers

Four Archetypes

Freud and Psychoanalysis (CW 4)

Mysterium Coniunctionis (CW 14)

On the Nature of the Psyche

The Practice of Psychotherapy (CW 16)

Psyche and Symbol

Psychiatric Studies (CW 1)

Psychogenesis of Mental Disease (CW 3)

Psychological Types (CW 6)

Psychology and Alchemy (CW 12)

Psychology and the East

Psychology and the Occult

Psychology and Western Religion

The Psychology of the Transference

The Spirit in Man, Art, and Literature (CW 15)

Symbols of Transformation (CW 5)

Synchronicity

Two Essays on Analytical Psychology (CW 7)

The Undiscovered Self

OTHER BOLLINGEN PAPERBACKS DEVOTED TO C. G. JUNG

C. G. Jung Speaking

C. G. Jung: Word \& Image

Complex/Archetype/Symbol in the Psychology of C. G. Jung

The Freud/Jung Letters (Abridged edition)

The Gnostic Jung

Jung on Active Imagination

Jung on Alchemy

Jung on Evil

Psychological Reflections 


\section{ON THE NATURE $\mathrm{OF}$}

\section{THE PSYGHE}

\section{G. JUN $G$}

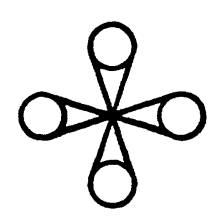

TRANSLATED BY R. F. C. HULL

B O L L I N G E N S E R I E S

P R I N C E T O N U N I VER S I T Y P R E S S 
COPYRIGHT (C) 1960 BY BOLLINGEN FOUNDATION, NEW YORK, N. Y.

PUBLISHED BY PRINCETON UNIVERSITY PRESS, PRINCETON, N. J.

Extracted from The Structure and Dynamics of the Psyche, Vol. 8 of the Collected Works of C. G. Jung. All the volumes comprising the Collected Works constitute number XX in Bollingen Series, under the editorship of Herbert Read, Michael Fordham, and Gerhard Adler; executive editor, William McGuire.

This book is sold subject to the condition that it shall not, by way of trade, be lent, resold, hired out, or otherwise disposed of without the publisher's consent, in any form of binding or cover other than that in which it is published.

FIRST PRINCETON / BOLLINGEN PAPERBACK PRINTING, 1969

Third Printing, 1973

LIBRARY OF CONGRESS CATALOG CARD NUMBER: 75-106803

ISBN $0-69^{1-0175^{1-4}}$

PRINTED IN THE UNITRD STATES OF AMERICA

$\begin{array}{lllllll}18 & 17 & 16 & 15 & 14 & 13 & 12\end{array}$

http://pup.princeton.edu 